\title{
Removal rate of compacted clay soil in the batch and continuous reactors and its permeability
}

\author{
G. Turkoglu Demirkol ${ }^{1}$, M. S. Ozcoban ${ }^{2 *}$, N. Tufekci $^{3}$ \\ ${ }^{1,3}$ Faculty of Engineering, Istanbul University, Istanbul, Turkey \\ ${ }^{2}$ Faculty of Civil Engineering, Yildiz Technical University, Istanbul, Turkey
}

\author{
Index Terms \\ Compacted Clay Soil \\ Permeability \\ Leachate \\ Adsorption \\ TKN \\ $\mathrm{TP}$
}

Received: 26 July 2017

Accepted: 5 September 2017

Published: 9 October 2017

\begin{abstract}
In Turkey, municipal solid wastes are primarily disposed in landfills. The infiltrated water in the landfill affects the chemical composition of leachate. The filtration, adsorption, dissolution, precipitation, ion exchange, and biochemical processes occur between the compacted clay soil and leachate. In this study, batch and continuous reactors are used to inveatigate permeability and adsorption of compacted clay soil. The clay soil, obtained from the Kemerburgaz-Odayeri landfill area on the European side of Istanbul, is put through standard and modified proctor compaction tests. The effects of Total Phosphorus (TP) and Total Kjeldahl Nitrogen (TKN) in the influent and effluent have been analyzed to determine the treatment capability for batch and continuous reactors of the compacted clay soil. The results of the permeability measurements using leachate show that the permeability in the compacted clay soil associated with the contamination is slightly increased. Removal efficiencies of TP in clay soil were obtained as $72 \%$ for standard compaction and $77 \%$ for modified compaction in continuous reactor. Also, TKN in clay soil was obtained as $60 \%$ for standard compaction and $81 \%$ for modified compaction in continuous reactor. Optimum adsorption time of TKN was 5 hours in batch reactor.
\end{abstract}

(c) 2017 The Author(s). Published by TAF Publishing.

\section{INTRODUCTION}

In Municipal Solid Waste (MSW) management, a lot of policies, plans, strategies, and methods have been improved. Landfills, especially sanitary landfills, reflect an applicable and the most commonly used implementation for solid waste disposal all over the world because it may achieve the reclamation of vacant area. However, other impacts may reveal from gas and leachate occurrence if not controlled well [1].

Leachate occurs from MSW during the landfill process because of several effects, such as precipitation, rainfall, surface runoff, biological degradation in the waste, etc., $[2,3]$. Landfill leachate possesses a dark color and a scent, which contains some organic and inorganic contaminants. Leachate has some pollutants in aqueous solution. Compacted clay soil has natural matters to minimize the perme- ability of soil liners in landfill areas [4]. Clay soil as natural, compacted, and consolidated various structures of clays and especially compacted clays due to their productiveness in relation to cost and large capacity of attenuation [5] could be used for leachate control in the landfills. In addition, the compacted clay soil has low permeability [4]. According to the design criteria of Turkish Solid Waste Management Legislation, the liner component is compacted to achieve hydraulic conductivity no greater than $10^{-8} \mathrm{~m} / \mathrm{s}$ [6].

Compacted clay soil may be affected negatively because of the matters on leachate. The suspended solid matters, layer expansion, ion adsorption, and bacterial clogging in the leachate may be different reasons for filling the spaces between the clay particles and this causes a reduction in the permeability. On one hand in a past study, permeability of compacted clay soil was not affected by the permeation of

\footnotetext{
* Corresponding author: M. S. Ozcoban

${ }^{\dagger}$ Email: ozcoban@yildiz.edu.tr
} 
compacted clay soil with diluted organic waste liquids while on the other hand, some other studies have also claimed that permeability of compacted clay soil was affected by pure organic waste liquids $[7,8,9,10]$.

The aim of this paper has been carried out in two stages. In the first stage, clays taken from KemerburgazOdayeri landfill area on the European side of Istanbul have been compacted and the permeability of the leachate has been investigated. Clay soil was put to the standard and modified proctor compaction tests. In the second stage, TKN and TP have been performed for the purpose of determining the treatment capacity of the compacted clay soil for batch and continuous reactors. These analyses have been conducted on the samples taken from the influent and effluent of the reactors treating the leachate.

\section{MATERIALS AND METHODS}

\section{A. Properties of the Clay Soil}

The clay soil samples were taken from KemerburgazOdayeri landfill area on the European side of Istanbul. The clay liner underlying domestic solid wastes stored in the Kemerburgaz-Odayeri solid waste landfill site is $60 \mathrm{~cm}$ thick with a permeability coefficient between $k=7.27 \times 10^{-7}$ and $5.32 \times 10^{-7} \mathrm{~m} / \mathrm{s}$.

The geomechanical properties of the clay soil from Kemerburgaz-Odayeri landfill area have been determined. Their color was brownish-gray. The kaolinite and illite have been considered to be true clay soil minerals. Soil samples contained: Natural Unit Weight $\left(\gamma_{n}\right), 2.0 \mathrm{~g} / \mathrm{cm}^{3}$, Natural Water Content $\left(\mathrm{W}_{n}\right), 30 \%$; Plastics Limit $\left(\mathrm{W}_{P}\right), 35 \%$; and Liquids Limit $\left(\mathrm{W}_{L}\right), 60 \%$; Plasticity Index $\left(\mathrm{I}_{p}\right), 40 \%$, Unit Weight of Soil Solids $\left(\gamma_{s}\right), 2.68 \mathrm{~g} / \mathrm{cm}^{3}$; and Dry Unit Weight $\left(\gamma_{k}\right), 1.6 \mathrm{~g} / \mathrm{cm}^{3}[11,12]$.

\section{B. Properties of the Leachate}

Leachate has dark brown color and very small granules, and also contains large amounts of organic and inorganic contaminants, and a high concentration of metals. The results of the characterization studies conducted on the leachate from the Kemerburgaz-Odayeri landfill area are presented in Table 1.

TABLE 1

PROPERTIES OF THE LEACHATE

\begin{tabular}{cccccccc}
\hline \hline & $\mathrm{pH}$ & $\begin{array}{c}\mathrm{COD} \\
(\mathrm{mg} / \mathrm{L})\end{array}$ & $\begin{array}{c}\mathrm{SS} \\
(\mathrm{mg} / \mathrm{L})\end{array}$ & $\begin{array}{c}\mathrm{TKN} \\
(\mathrm{mg} / \mathrm{L})\end{array}$ & $\begin{array}{c}\mathrm{NH}_{4}-\mathrm{N} \\
(\mathrm{mg} / \mathrm{L})\end{array}$ & $\begin{array}{c}\text { Org-N } \\
(\mathrm{mg} / \mathrm{L})\end{array}$ & $\begin{array}{c}\mathrm{TP} \\
(\mathrm{mg} / \mathrm{L})\end{array}$ \\
\hline \hline Sample 1 & 7.9 & 18725 & 1878 & 2752 & 2310 & 325 & 18 \\
Sample 2 & 7.6 & 17650 & 1427 & 2910 & 2543 & 203 & 22 \\
\hline \hline
\end{tabular}

\section{Permeability Tests}

Compaction is a laboratory or in-situ soil improvement method which rearranges and densifies soil particles through the application of mechanical energy and thereby increases its dry density where the air-voids are reduced for specific purposes, such as increasing bearing capacity, shear strength, and reducing permeability and settlement.

Standard (ASTM D698/AASHTO T99) and Modified Proctor (ASTM D1557/AASHTO T180) methods are commonly applied in the laboratory at different water contents in a mould $(0.102 \mathrm{~m}$. ID X $0.117 \mathrm{~m}$. H) and vary only in the amount of applied energy to determine the maximum dry density-water content relationship. Standard Proctor involves 25 drops of a $24.5 \mathrm{kN}$ hammer from a height of 0.305 meters and three soil layers. The Modified Proctor uses a $45 \mathrm{kN}$ hammer, a fall of 0.45 meters on five layers of soil,

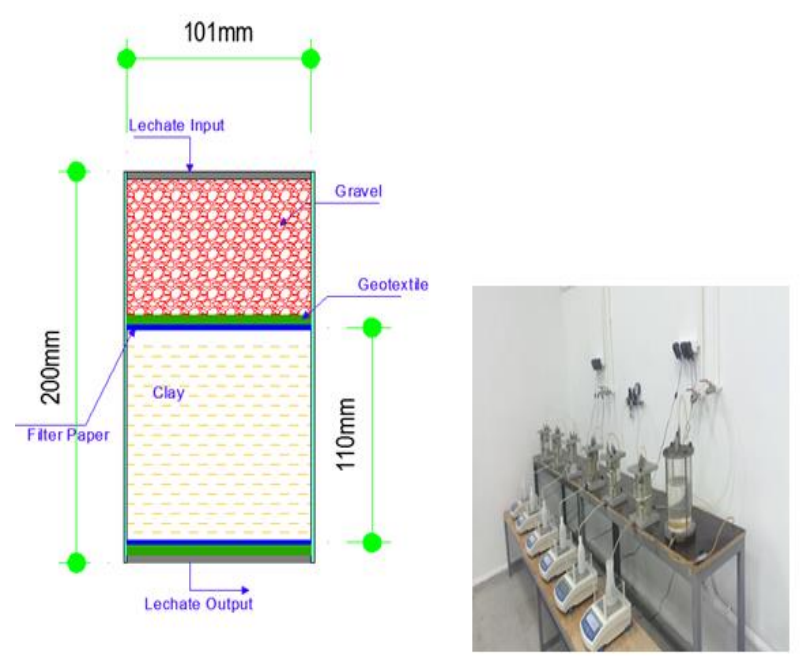

Fig. 1. Graphics and photography of experimental setup 
i.e., a higher compactive energy [13]. The reactor tests have been performed by flowing the liquid downwards through $100 \mathrm{~mm}$ diameter compacted specimens. The height of the compacted clay soil was $110 \mathrm{~mm}$. The soil was constrained against swelling. The clay soil has been saturated under a 0.3 -bar pressure [14, 15]. Experimental setup is given in Figure 1.

Constant Head Tests, using the following equation, have been performed to find the coefficient of permeability of the clay soil:

$k=\frac{Q L}{\operatorname{At}\left(h_{1}-h_{2}\right)}$

where,

$k$ : Coefficient of permeability, $\mathrm{cm} / \mathrm{s}$;

$A$ : Surface area of the specimen, $\mathrm{cm}^{2}$;

$L$ : Distance between the manometers, $\mathrm{cm}$;

$\left(h_{1}-h_{2}\right)$ : Differential head across the sample, $\mathrm{cm}$;

$Q$ : Total discharge, $\mathrm{cm}^{3} / \mathrm{s}$;

$t$ : elapsed time, s.

\section{Adsorption Experiments}

In this study, clay taken from Kemerburgaz-Odayeri landfill area of İstanbul changing color from yellow to brown was used as an adsorbent $[16,17,18,19]$. Adsorption experiments were carried out via lab scale batch system. The shaking process was carried out at a $100 \mathrm{rpm}$ spin rate using a Zhicheng ZHWY-211B model shaking incubator. $250 \mathrm{~mL}$ samples at $\mathrm{pH} 7.5$ were shaken for 5 hours at $100 \mathrm{rpm}$. After 5 hours, samples were allowed to settle. The adsorption capacities of Kemerburgaz-Odayeri landfill area clay soil were determined for TKN by the batch system. During the period of study, the $\mathrm{pH}$ level of the leachate from the sanitary landfill was approximately 7.5 (between 7.6-7.9). Langmuir and Freundlich isotherm models were applied to establish the relationship between the amount of TKN adsorbed to clay soil and the amount of clay. For determining the adsorption isotherm, initial TKN concentrations were varied between $0.25,0.5,1,2.5,5$, and $10 \mathrm{~g} / \mathrm{L}$. Afterwards, $250 \mathrm{~mL}$ of leachate and $2.5 \mathrm{~g} / \mathrm{L}$ adsorbent were placed in a flask. The leachate was diluted 50, 80, 90, 95, and $97.5 \%$ with distilled water prior to testing to obtain various data points for the adsorption isotherms. The $\mathrm{pH}$ of the solution was set to 7.5 and the flask was shaken with a thermostated shaker for different contact times. 5 hours was selected as the optimum retention time for this study.

\section{E. Analysis}

Aiming to obtain the removal capacity of the compacted clay soil, TKN and TP have been measured according to Standart APHA Methods both in the influent and effluent of the batch and continuous reactors [20].

\section{RESULTS AND DISCUSSION}

\section{A. Results of the Compaction and Permeability Tests}

Compaction tests were caried out to obtain maximum dry density and optimum water content, and average values were obtained from permeability tests. The average permeability has the lowest value when prepared with the optimum water content both for standard and modified Proctor compaction tests, which matches well with earlier studies.

The optimum water content of the standard Proctor compaction tests result was $25 \%$ and the optimum water content was $21 \%$ in the modifiying Proctor compaction test. The obtained permeability results are shown in Figure 2.

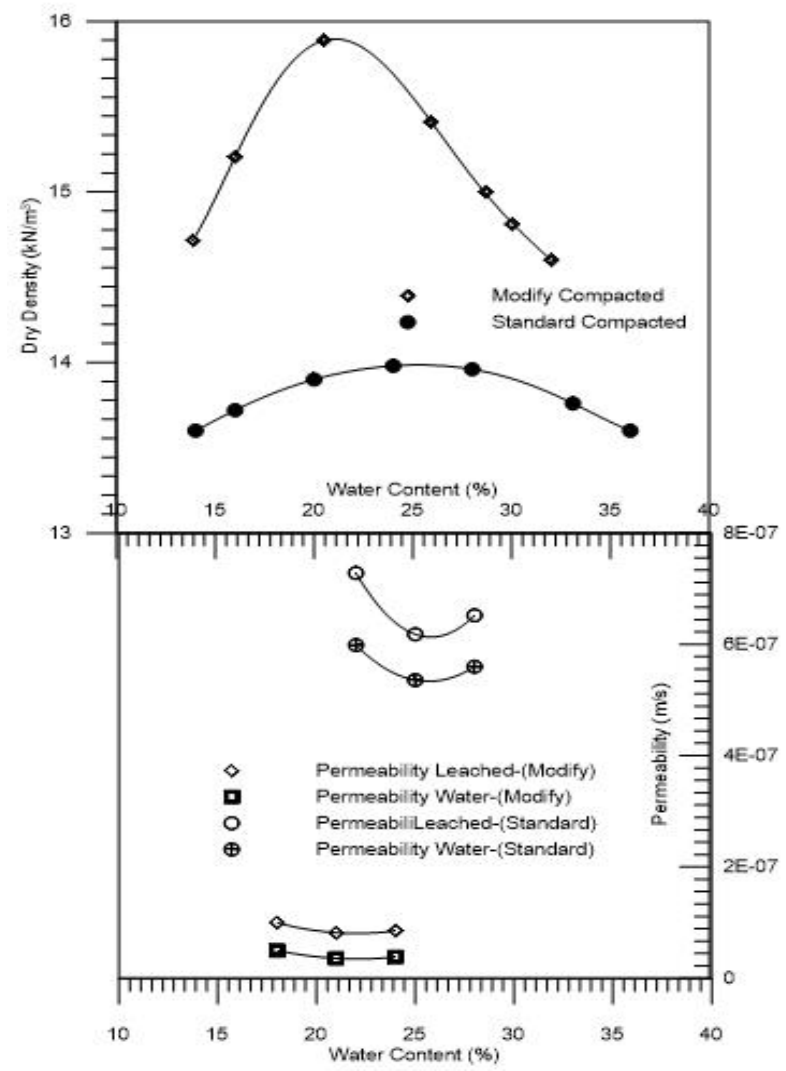

Fig. 2. Results of standard and modified Proctor compaction and permeability tests 
The permeability of the current clay soil in Kemerburgaz-Odayeri landfill area is measured between $k=7.27 \times 10^{-7}$ and $5.32 \times 10^{-7} \mathrm{~m} / \mathrm{s}$. The permeability is increased when clay soil samples are leached with TKN and TP, which clearly can be seen from Figure 2 .

\section{B. Removal Rate of TKN and TP}

Laboratory experiments for investigating the influence of TKN and TP on permeability of compacted clay soil have been performed for 300 days. With the purpose of determining treatment capability of compacted clay soil, TKN and TP were measured in analytical tests performed on influent and effluent [20]. The results are given in Figures 3-6.
Influent TKN concentration of leachate was measured to be $2910 \mathrm{mg} / \mathrm{L}$. After 20 days, permeant (water) was replaced by the leachate, and effluent TKN concentration and efficiency have been determined to be $1283 \mathrm{mg} / \mathrm{L}$ and $56 \%$ respectively (Figure 3). It is believed that the sharp decrease in the effluent concentration is caused by replacing water with leachate between the $20^{t h}$ and the $40^{t h}$ day of the experiment, leachate penetration took place in the compacted clay soil, and water completely left the system. Effluent TKN concentrations of leachate were measured to be $1163 \mathrm{mg} / \mathrm{L}$ and removal rate efficiencies $60 \%$ for sample prepared at optimum water contents of $25 \%$ have been obtained on the 40th day for samples compacted at standard Proctor energy (Figure 3).

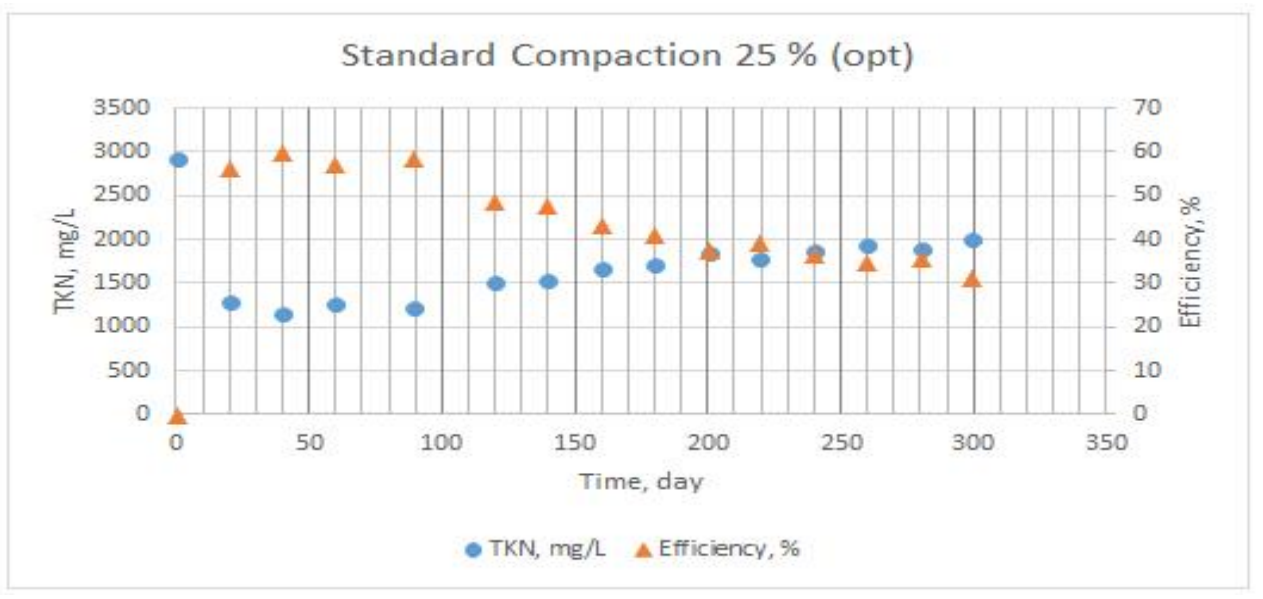

Fig. 3. Removal rate of TKN in continuous reactors

The breakthrough time of the leachate through the clay soil is 40 days. Adsorption continues for 300 days. However, the efficiency of the removal rate decreases after the 40th day. Change in removal rate can be explained with the adsorption up to the $40^{\text {th }}$ day and desorption afterwards.

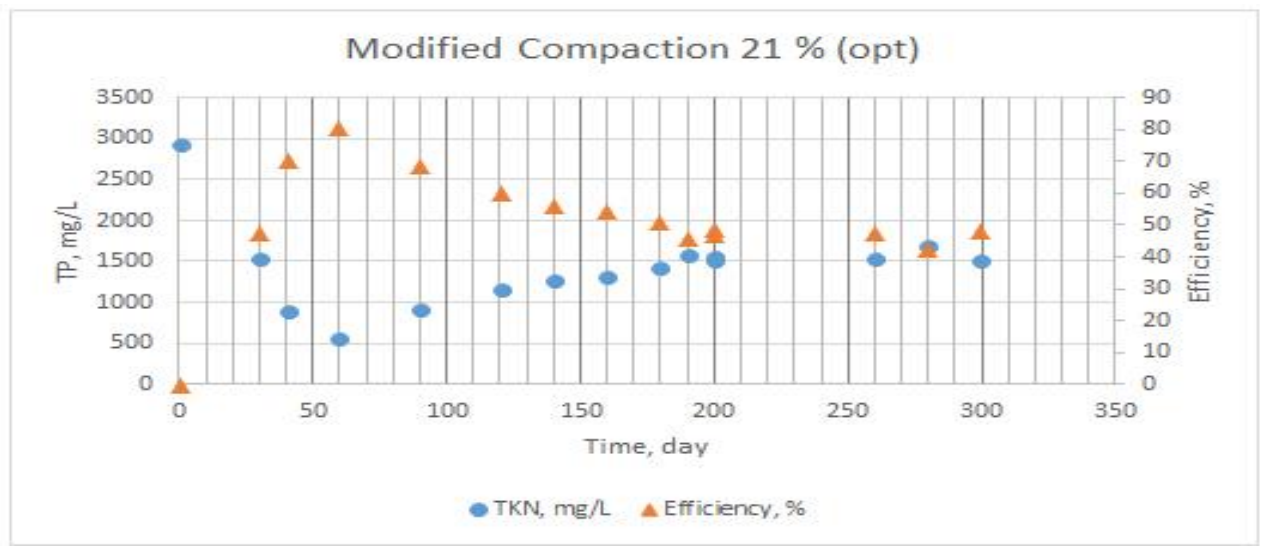

Fig. 4 . Removal rate of TKN in continuous reactors 
The measured TKN concentration of the leachate is $2910 \mathrm{mg} / \mathrm{L}$, which is permeated through the soil compacted at differing water contents utilizing the modified Proctor energy. The breakthrough time of the leachate through the clay soil is 60 days.

Removal rate of $81 \%$ was obtained for sample compacted at modified Proctor water contents of $21 \%$ on the $60^{\text {th }}$ day, but decreased after the $60^{\text {th }}$ day (Figure 4). Removal rate behavior can be explained with adsorption criteria up to the $60^{\text {th }}$ day and desorption afterwards. TKN removal rate for samples prepared with modified Proctor compactive energy was found to be higher than the ones prepared with standard Proctor method. Initial TP concentration of leachate was measured to be $22 \mathrm{mg} / \mathrm{L}$. After 30 days, permeant (water) was replaced by the leachate.

Removal rate efficiency has been determined to be $72 \%$ at optimum water contents of $25 \%$ obtained on the $40^{\text {th }}$ day for samples prepared with standard Proctor compaction effort (Figure 5). Adsorption continues up to the $300^{\text {th }}$ day. However, in general, the efficiency of the removal rate decreases after the $40^{\text {th }}$ day. Removal rate behavior can be explained with adsorption criteria up to the $40^{\text {th }}$ day and desorption afterwards.

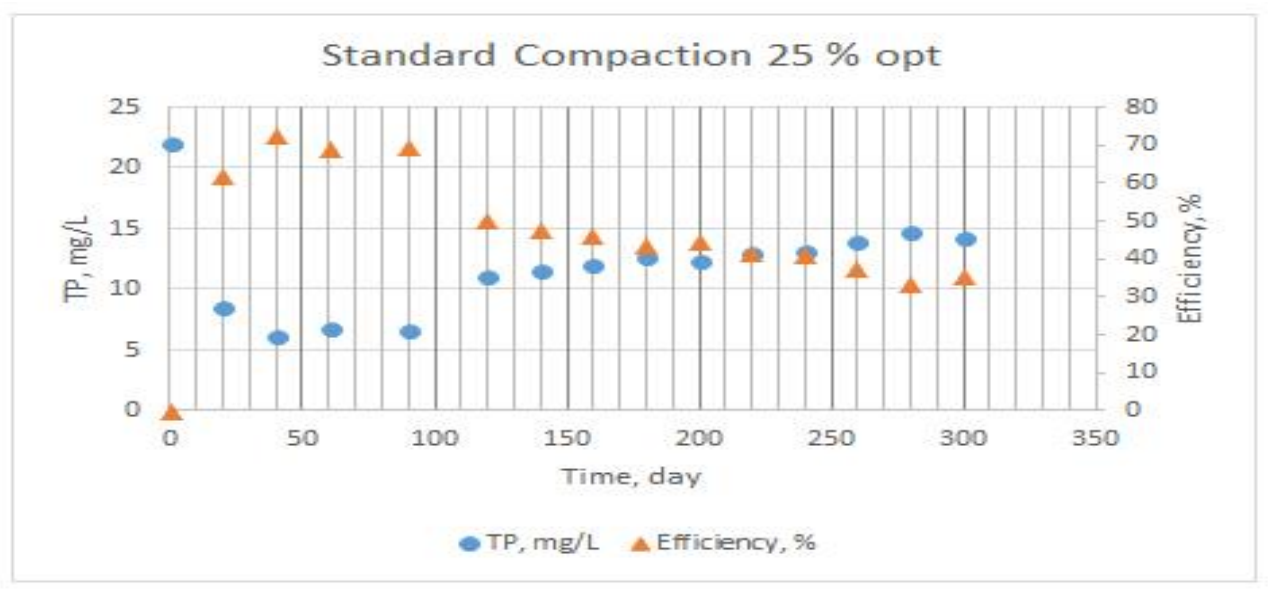

Fig. 5 . Removal rate of TP in continuous reactors

The measured TP input value of the leachate is $22 \mathrm{mg} / \mathrm{L}$ which is permeated through the soil compacted at differing water contents utilizing the Modified Proctor energy. The breakthrough time of the leachate through the clay soil is 60 days. Removal rate of $77 \%$ was obtained for sample compacted with the modified Proctor effort and water contents of $21 \%$ on the $60^{t h}$ day, which decreased after the $60^{t h}$ day to approximately $39 \%$ on the $300^{\text {th }}$ day (Figure 6). TP removal rates for sample prepared with the Modified Proctor compaction method were higher than those prepared with Standard Proctor Method. The TKN and TP removal rate efficiency of the clay soil is significantly high.

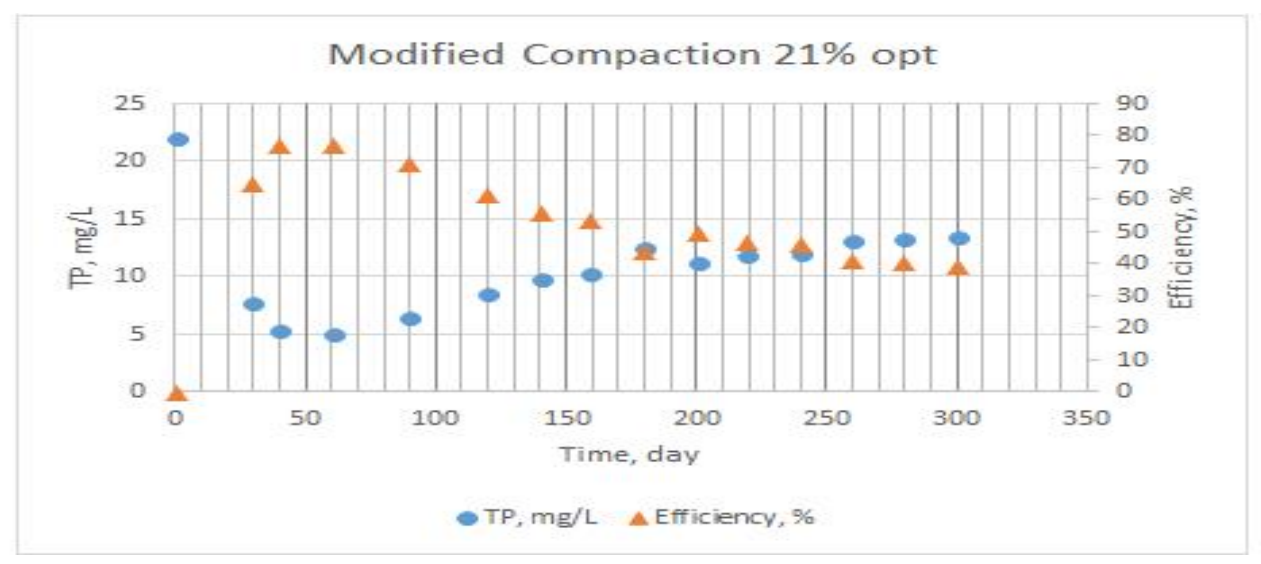

Fig. 6. Removal rate of TP in continuous reactors 
C. Adsorption Isotherm of TKN and TP in the Batch Reactors

To determine the different amount of TKN concentrations on adsorption, isotherm experiments were carried out. The data derived from the adsorption isotherm experiments were applied to the Freundlich and Langmuir isotherm models, which are given as follows:

$\log q_{e}=\log K_{f}+\frac{1}{n} \log c_{e}$

where,

$q_{e}$ : Adsorbed TKN concentration, $\mathrm{mg} / \mathrm{g}$;

$c_{e}$ : Concentration of TKN in the solution at equilibrium, $\mathrm{mg} / \mathrm{L}$;

$K_{f}$ : Freundlich affinity coefficient, $\mathrm{mg} / \mathrm{g}$.

Depending on the linear form of the adsorption isotherm obtained from plots of $\log c_{e}$ versus $\log q_{e}$, constants were calculated from the slope of the graph. The other equation conforming to the results of the adsorption isotherm is given as:

$\frac{C_{e}}{q_{e}}=\frac{1}{q_{m} K}+\frac{c_{e}}{q_{m}}$ where,

$q_{e}$ : Amount of adsorbed TKN concentration, mg/g;

$c_{e}$ : Concentration of TKN in the solution at equilibrium, $\mathrm{mg} / \mathrm{L}$;

$q_{m}$ : Capacity parameter, $\mathrm{mg} / \mathrm{g}$;

$K$ : Langmuir constant, $\mathrm{L} / \mathrm{mg}$.

Depending on the linear form of the adsorption isotherm obtained from plots of $C_{e}$ versus $c_{e} / q_{e}$, constants were calculated from the slope of the graph. These Freundlich and Langmuir isotherm models have been widely used by researchers to account for the dosage effects when observing the adsorption of organic matters [21, 22]. Figures 7-8 show Langmuir and Freundlich-type adsorption isotherms of clay taken from Kemerburgaz-Odayeri Area (TKN at pH 7.5, 5 hours' retention time, and $250 \mathrm{~mL}$ solution contacted with $2.5 \mathrm{~g}$ adsorbent). $R^{2}$, the correlation coefficient, of Freundlich is (0.9858) being higher than the Langmuir isotherm (0.808). This study, carried out with TKN based on the $R^{2}$ values, shows that the Freundlich isotherm fits the experimental data better than the Langmuir isotherm.

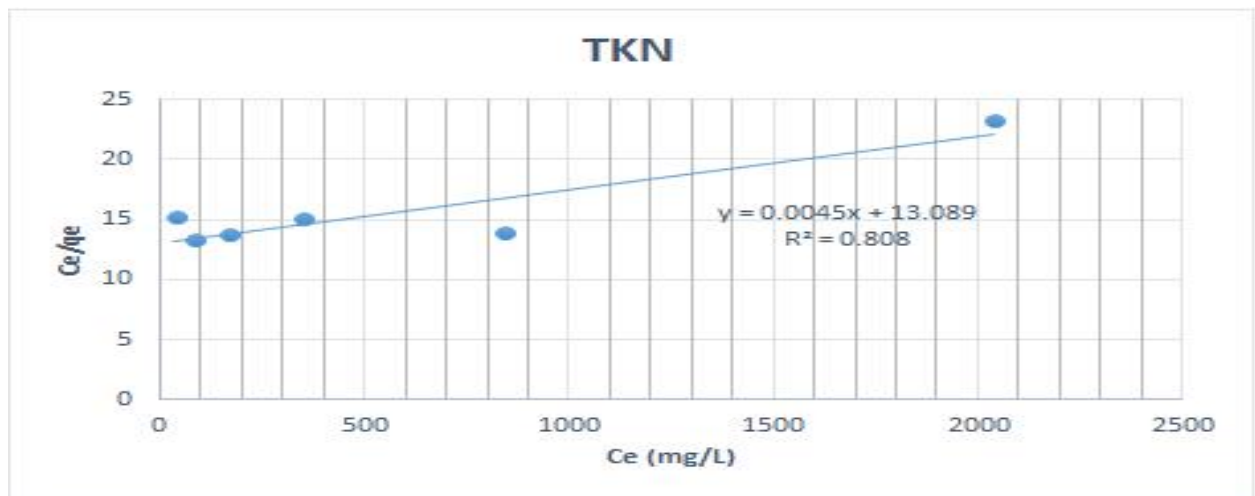

Fig. 7 . Linearized Langmuir isotherm of Kemerburgaz-Odayeri clay soil for TKN

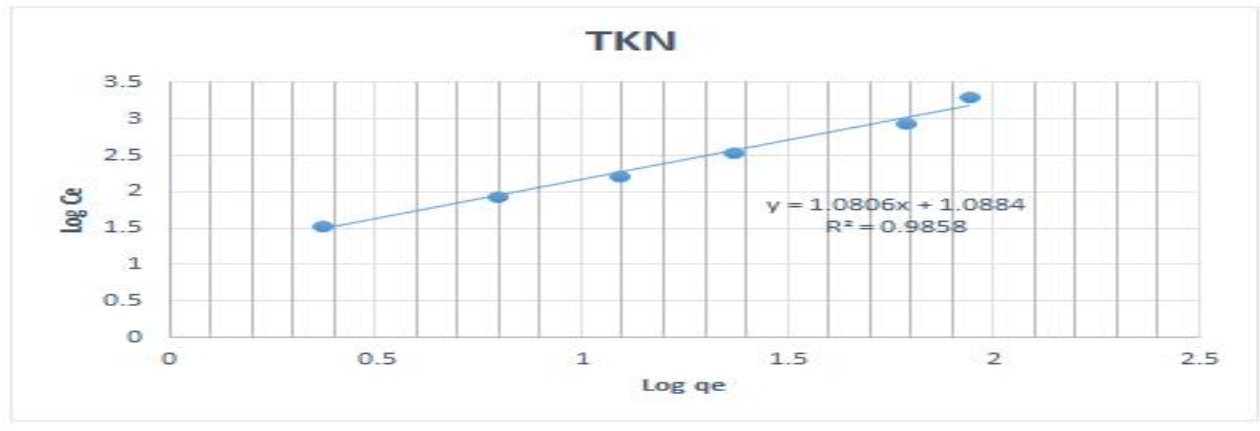

Fig. 8 . Linearized Freundlich isotherm of Kemerburgaz-Odayeri clay soil for TKN 
TKN concentration is significantly higher than TP (TKN $2910 \mathrm{mg} / \mathrm{L}$, TP $22 \mathrm{mg} / \mathrm{L}$ ). For this reason, the same conditions can not be established and the isotherm cannot be applied because it is below measurable limits in batch experiments.

\section{CONCLUSION}

In this study, it is found that the permeability is increased depending on deformation on clay soil caused by leachate.

The results came out from the continuous reactor showing that removal rates of TP in clay soil are $72 \%$ and $77 \%$ for standard compaction and modified compaction respectively. TKN in clay soil is around $60 \%$ and $81 \%$ for standard compaction and modified compaction respectively. TP and TKN removal efficiencies for standard compaction were higher than modified compaction. In adsorption experiments made with clay soil, the average yield of $40 \%$ is obtained. On a continuous basis/system, the average removal efficiency was around $70 \%$. As can be understood from this, $40 \%$ of the adsorption mechanism is effective in nitrogen removal, while the remaining part is affected by mineralization, nitrification, ion exchange, complexation, biological use, and denitrification mechanisms. In batch reactor adsorption studies, maximum adsorption time for TKN was found to be $5 \mathrm{~h}$. For longer shaking processes, efficiency of adsorption decreases, since not only desorption but also adsorption occurs. Adsorption results are consistent with Freundlich isotherm. The $R^{2}$ value indicated that TKN fits the experimental data better than Langmuir isotherm. Phosphorus can easily be removed from the soil by means of mainly adsorption and chemical precipitation. The adsorptive surfaces of the soil particles are regenerated by adsorption mechanism and the active zones of the soil particles are filled while the phosphine builds complexes with aluminum, calcium, and iron so they become insoluble. In this respect, phosphorus can be retained in the soil without leaking far away.

\section{ACKNOWLEDGMENT}

This study was supported by the Research Fund of Istanbul University, Project number BEK-2017-24711.

\section{REFERENCES}

[1] M. M. Abd El-Salam and G. I. Abu-Zuid, "Impact of landfill leachate on the groundwater quality: A case study in
Egypt," Journal of Advanced Research, vol. 6, no. 4, pp. 579-586, 2015. DOI: 10.1016/j.jare.2014.02.003

[2] E. Bou-Zeid and M. Ei-Fadel, "Parametric sensitivity analysis of leachate transport simulations at landfills," Waste Management, vol. 24, no. 7, pp. 681-689, 2004. DOI: 10.1016/j.wasman.2004.03.004

[3] Q. Xue, J. S. Li and L. Liu, "Experimental study on antiseepage grout made of leachate contaminated clay in landfill," Applied Clay Science, vol. 80-81, pp. 438-442, 2013. DOI: $10.1016 /$ j.clay.2013.06.026

[4] E. A. M. Yahia, A. Al, R. Amer, Y. Al, A. Mohammed, Q. Ahmed and R. Al, Abdul-Hamid, "Assessment of crushed shales for use as compacted landfill liners," Engineering Geology, vol. 80, no. 3, pp. 271-281, 2005. DOI: 10.1016/j.enggeo.2005.06.001

[5] M. S. Ozcoban, N. Cetinkaya, S. O. Celik, G. T. Demirkol, V. Cansiz and N. Tufekci, "Hydraulic conductivity and removal rate of compacted clays permeated with landfill leachate," Desalination and Water Treatment, vol. 51, no. 31/33, pp. 6148-6157, 2013.

DOI: $10.1080 / 19443994.2013 .769662$

[6] H. Brandl, "Mineral liners for hazardous waste containment," Geotechnique, vol. 42, no. 1, pp. 57-65, 1992.

DOI: $10.1680 /$ geot.1992.42.1.57

[7] D. E. Daniel, "Predicting hydraulic conductivity of clay liners," Journal of Geotechnical Engineering, vol. 110, no. 2, pp. 288-300, 1984.

[8] K. W. Brown and D. C. Anderson, "Effects of organic solvents on the permeability of clay soils," 1983 [Online]. Available: goo.gl/bG2JAG

[9] K. W. Brown, J. C. Tomas and J. W. Green, "Permeability of compacted soils to solvents mixtures and petroleum products," 1984 [Online]. Available: goo.gl/immKUC

[10] W. J. Green, G. F. Lee and R. A. Jones, "Clay-soils permeability and hazardous waste storage," Journal Water Pollution Control Federation, vol. 53, no. 8, pp. 1347-1354, 1981.

[11] M. Ş. Ozcoban, "Permeability and removal rate of compacted clays to organic and inorganic matters," Journal of Scientific and Industrial Research, vol. 67, no. 2, pp. 136-143, 2008.

[12] N. Tufekci, M. Ozcoban, S. Yalcın, Y. Ascı and C. Akgüner, "Adsorption and permeability of clays permeated with ferrous iron and manganese," Fresenius Environmental Bulletin, vol. 19, no. 8, pp. 1703-1714, 2010.

[13] American Society for Testing \& Materials, "Standard test method for laboratory determination of water (Mois-

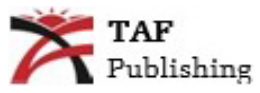


ture) content of soil and rock by mass," 1998 [Online]. Available: goo.gl/eAVZbp

[14] D. E. Daniel, D. C. Anderson and S. S. Boynton, "Fixedwall versus flexible-wall permeameters," Hydraulic Barriers in Soil and Rock, vol. 3, no. 5, pp. 107-126, 1985. DOI: $10.1520 / \operatorname{stp} 34573 \mathrm{~s}$

[15] T. Zimmie, "Geotechnical testing considerations in the determination of laboratory permeability for hazardous waste disposal siting," ASTM Special Technical Publication, vol. 3, no. 760, pp. 293-304, 1981.

DOI: $10.1520 /$ stp28842s

[16] S. Yıldız, "Report on the renovation project for Komurcuoda landfill," 2000 [Online].

Available: goo.gl/SHTFzK

[17] M. Attom, M. Kou and N. Al-Akhras, "Geo environmental utilization of iron-filing with cement in soil stabilization," International Journal of Technology and Engineering Studies, vol. 2, no. 2, pp. 32-37, 2016.

DOI: $10.20469 /$ ijtes.2.40001-2

[18] K. Özaydın, S. Yıldırım and M. Yıldırım, "Environmental impact assessment report regarding geological- hydrogeological conditions of Kemerburgaz landfill site located in the European side of Istanbul," 1996 [Online]. Available: goo.gl/yRXKSy

[19] A. Baştürk, M. Öztürk, A. Demir and G. Kanat, "Kömürcüoda (Asian side of Istanbul) fill area solid waste Environmental Impact Assessment (EIA)," 1996 [Online]. Available: goo.gl/xfpYSX

[20] A. E. Greenberg, "Standard methods for the examination of water and wastewater," Washington, Washington, DC, WA: American Public Health Association, 2005.

[21] H. T. Wang, A. A. Keller and F. T. Li, "Natural organic matter removal by adsorption onto carbonaceous nanoparticles and coagulation," Journal of Environmental Engineering, vol. 136, no. 10, pp. 1075-1081, 2010.

DOI: $10.1061 /$ (asce)ee.1943-7870.0000247

[22] H. Maizir, R. Suryanita and H. Jingga, "Estimation of pile bearing capacity of single driven pile in sandy soil using finite element and artificial neural network methods," International Journal of Applied and Physical Sciences, vol. 2, no. 2, pp. 45-50, 2016.

DOI: /10.20469/ijaps.2.50003-2

— This article does not have any appendix. — 